\title{
Hardening and properties of cement-based materials incorporating heavy metal oxides
}

\author{
V ŽIVICA \\ Institute of Construction and Architecture of the Slovak Academy of Sciences, Bratislava, \\ Slovak Republic \\ MS received 2 January 1995; revised 7 May 1997

\begin{abstract}
The subject of the study was the influence of oxides $\mathrm{PbO}, \mathrm{ZrO}_{2}$ and $\mathrm{Cr}_{2} \mathrm{O}_{3}$ immobilized in cement matrix. The obtained results show the positive effect of the present oxides in hydrating cement on compressive strength development and the quality of the formating pore structure of the resulting material.

A surprising effect showing the paralysis of the positive effect of heavy metal oxide admixture has been shown by the increasing of the added quantity of $\mathrm{PbO}$ (from 1 to $4 \%$ ) and the used $\mathrm{w} / \mathrm{c}$ ratio $(0.7$ instead of 0.4$)$. The increase of the quantity overcoming the optimum of the reaction product of the interaction between hydrating cement and $\mathrm{PbO}$ added for the cause of the paralysis is supposed. The explanation of the adverse effect and the identification of the reaction product in question needs more detailed study.
\end{abstract}

Keywords. Heavy metal oxides; cement matrix; immobilization.

\section{Introduction}

Solidification and stabilization in cement systems is one from the possibilities of measures aiming at minimizing the environmental risk associated with handling of hazardous wastes. Solidification with cements offers three major advantages: (i) the technology involved in the fabrication of the waste form is simple and available; (ii) a series of studies throughout the world has verified the availability of properties of tailored cementitions formulations and (iii) perhaps most importantly, there is a potential advantage of near-thermodynamic stability offered by a hydrated encapsulent host material. With the exception of the simple four-coordinated oxides of $\mathrm{Si}, \mathrm{Ti}, \mathrm{U}$ and $\mathrm{Th}$, all potential host phases are hydrated at the normally surrounding conditions of temperature and pressure forming thermodynamically stable form (Roy 1982).

Among the different types of wastes one can distinguish between: (i) wastes containing significant quantities of intractable inorganic elements, such as heavy metal oxides like cadmium, mercury, arsenic, selenium, lead, zinc and copper, (ii) radioactive wastes and (iii) wastes containing significant quantities of toxic, hazardous or polluting organic compounds, which cannot be re-processed or recycled utilizing current technologies.

A major point of concern refers to the long-term behaviour of the resulting waste-cement composed products. In this connection it is important to classify the effect of interfering compounds on the hydration of Portland cement (Takashi et al 1977). A special attention to the immobilization of heavy metals is paid. These can occur even as radioactive wastes.

The use of Portland cement and its blended species for this purpose is well documented (Gilliam et al 1986). The successful immobilization of heavy metals such as $\mathrm{Cr}, \mathrm{Pb}, \mathrm{Ba}, \mathrm{Hg}, \mathrm{Cd}$ and $\mathrm{Zn}$ in cement systems is generally attributed to adsorption 
and precipitation of hydroxide phases. In general, transition element compounds, added in cement strongly affect the hydration process. The compounds, e.g. such as $\mathrm{PbO}$ and $\mathrm{ZnO}$ delay setting and hardening (Barth et al 1990; Arliquie et al 1983). An exception represents $\mathrm{Cr}$ compounds accelerating hardening (Fierens and Verhaegen 1972).

An interesting topic represents the influence of present heavy metal oxides on electrochemical behaviour of embedded steel reinforcement. According to the information given in some papers and our results, oxides $\mathrm{ZnO}, \mathrm{CuO}$ and $\mathrm{PbO}$ represent effective inhibitors of chloride-induced corrosion of concrete steel reinforcement (Tashiro 1984; Tashiro et al 1985). On the contrary $\mathrm{Cr}_{2} \mathrm{O}_{3}$ and $\mathrm{MnO}$ act as corrosionstimulating compounds. According to our results the oxides $\mathrm{Cr}_{2} \mathrm{O}_{3}, \mathrm{Fe}_{2} \mathrm{O}_{3}, \mathrm{~V}_{2} \mathrm{O}_{5}$, $\mathrm{CdO}, \mathrm{TiO}_{2}$ and $\mathrm{MoO}_{3}$ have been shown as strong corrosion-stimulating substances (Živica and Vargová 1995; Živica and Janotka 1996). Exceptionally strong stimulating is $\mathrm{WO}_{3}$, causing the total dissolution of steel (Živica 1994).

This study involves series of experiments concerning the influence of heavy metal compounds on hydration and hardening of cement-based materials.

The subject of the paper is the influence of admixture of some heavy metal oxides on the long-term properties of cement based materials.

\section{Experimental}

The information on the experimental work is given in table 1 .

\section{Results and discussion}

Figures 1 and 2 show the values of compressive strength of the mortars with metal oxide admixtures ( $\mathrm{MeO}_{x}$ mortars). The presented values are expressed by the percentage of compressive strength of mortars without $\mathrm{MeO}_{x}$ admixture (plain mortars).

Table 1. Experimental conditions

\begin{tabular}{|c|c|}
\hline $\begin{array}{l}\text { Test specimens } \\
\text { composition }\end{array}$ & $\begin{array}{l}\text { Mortar with cement: sand is in the ratio of } 1: 3, \mathrm{w} / \mathrm{c} 0.5 \text { and } 0.7,1 \text { and } \\
4 \% \mathrm{PbO}, \mathrm{ZrO}_{2} \text { and } \mathrm{Cr}_{2} \mathrm{O}_{3} \text { admixture from the mass of cement, control } \\
\text { mortar without metal oxide admixtures }\end{array}$ \\
\hline Curing & $\begin{array}{l}3 \text { days at } 95 \% \mathrm{RH} \text { and } 20^{\circ} \mathrm{C} \text { in moulds (moist curing), after demoulding at } \mathrm{RH} \text { of } \\
50 \% \text { and } 20^{\circ} \mathrm{C} \text { (air curing). Owning to the delayed hardening of the } \mathrm{PbO} \text { mortars } \\
\text { their moist curing has been prolonged to } 10(1 \% \mathrm{PbO}, \mathrm{w} / \mathrm{c} 0.5), 14(1 \% \mathrm{PbO} \text {, } \\
\mathrm{w} / \mathrm{c} 0.7) \text { and } 30 \text { days }(4 \% \mathrm{PbO}, \mathrm{w} / \mathrm{c} 0.5 \text { and } 0.7)\end{array}$ \\
\hline Test specimens size & $20 \mathrm{~mm}$ edge cubes \\
\hline Materials used & $\begin{array}{l}\text { Portland cement CEM I } 42.5 \text { according to STN PENV 197-1 (table 2), silica sand } \\
\text { according to STN } 721208 \text {, commercially available oxides } \mathrm{PbO}, \mathrm{ZrO}_{2} \text { and } \mathrm{Cr}_{2} \mathrm{O}_{3}\end{array}$ \\
\hline Properties studied & $\begin{array}{l}\text { Setting of the cement pastes with w/c } 0.3 \text { and } 0.45 \text { and addition of } 1.0 \text { and } 4.0 \% \\
\text { PbO, according to STN } 722115 \text {. } \\
\text { Bulk weight, compressive strength, total porosity calculated from specific and bulk } \\
\text { weights, pore structure (mercury porosimetry mod. } 2000 \text { and macroporosimeter } \\
120 \text { Carlo Erba), composition (diffractograph Philips and DTA), bound water and } \\
\text { calcium hydroxide contents (thermogravimetrically). For DTA and GTA equip- } \\
\text { ment of MOM Budapest was used. }\end{array}$ \\
\hline
\end{tabular}




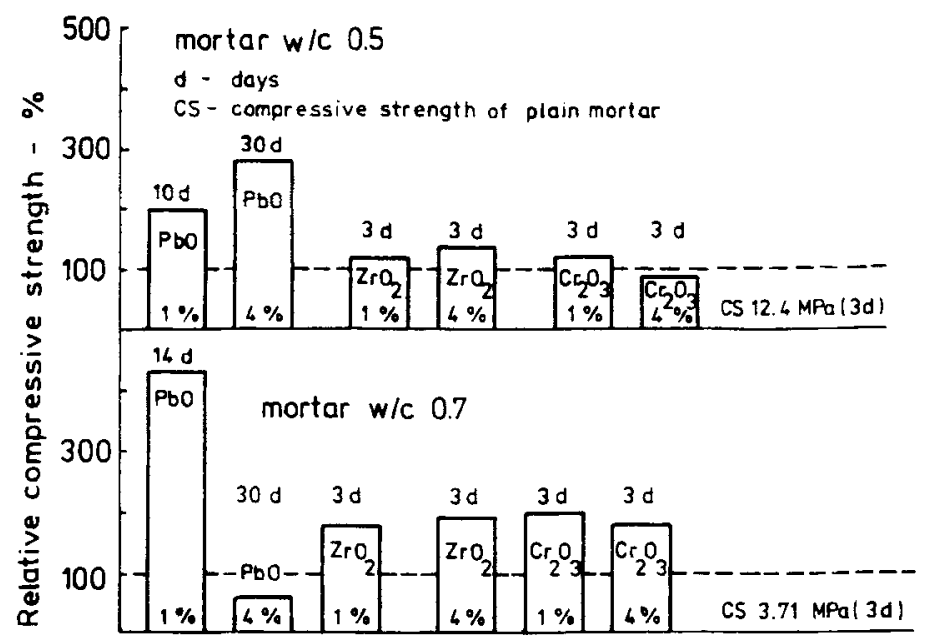

Figure 1. Compressive strength of the mortars after their moist curing.

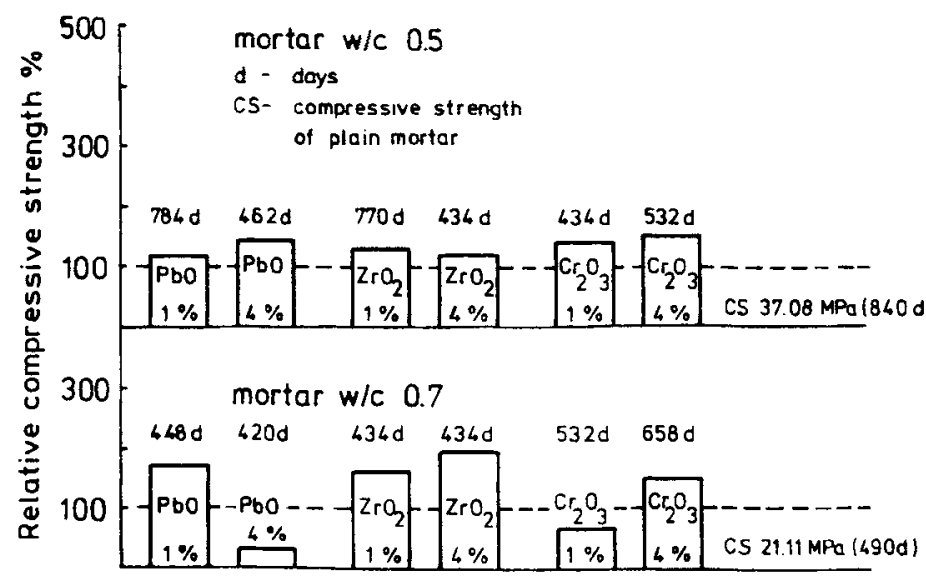

Figure 2. Compressive strength of the mortars after their air curing.

Figure 1 shows that $\mathrm{PbO}, \mathrm{ZrO}_{2}$ and $\mathrm{Cr}_{2} \mathrm{O}_{3}$ as admixtures accelerated the hardening of the mortars. This effect by the accelerated development of compressive strength of the related mortars has been shown. This accelerating effect by the increased $\mathrm{w} / \mathrm{c}$ value was expressed.

According to figure 1 the accelerating effect was especially expressed in $\mathrm{PbO}$ admixture. Evidently, the efficiency of this admixture positively influenced the prolonged moist curing of the $\mathrm{PbO}$ mortars (table 1). This has been caused by the slowingdown of setting of the mortars. It can be supposed that the real accelerating effect of the $\mathrm{PbO}$ admixture is not so expressive as shown in figure 1 . But, in any case, it can be considered as equivalent to the accelerating effect generated by the $\mathrm{ZrO}_{2}$ and $\mathrm{Cr}_{2} \mathrm{O}_{3}$ admixtures. This assumption is confirmed by the comparable long-term values of compressive strength of the $\mathrm{MeO}_{x}$ mortars (figure 2). The slowing-down of the cement pastes caused by $\mathrm{PbO}$ admixture is well demonstrated (table 3 ). Again the adverse effect of $\mathrm{PbO}$ admixture, depending on $\mathrm{w} / \mathrm{c}$ ratio value used can be seen. 
Table 2. The properties of used Portland cement.

\begin{tabular}{|c|c|c|c|c|c|c|c|c|}
\hline \multicolumn{9}{|c|}{ Composition (\%) } \\
\hline $\begin{array}{l}\text { Ignition } \\
\text { loss }\end{array}$ & $\begin{array}{l}\text { Insoluble } \\
\text { residue }\end{array}$ & $\mathrm{SiO}_{2}$ & $\mathrm{Al}_{2} \mathrm{O}_{3}$ & $\mathrm{Fe}_{2} \mathrm{O}_{3}$ & $\mathrm{CaO}$ & $\mathrm{MgO}$ & $\mathrm{SO}_{3}$ & Total \\
\hline 1.07 & 1.29 & $20 \cdot 57$ & $5 \cdot 84$ & 3.06 & $64 \cdot 42$ & 1.50 & $2 \cdot 15$ & $99 \cdot 9$ \\
\hline Setting & $\begin{array}{l}\text { begin } \\
\text { end }\end{array}$ & \multicolumn{3}{|c|}{$\begin{array}{l}3 \mathrm{~h} 30 \mathrm{~min} \\
5 \mathrm{~h}\end{array}$} & \multicolumn{2}{|c|}{$\begin{array}{c}\text { Specific weight } \\
\text { kg.m } \mathrm{m}^{-3} \\
3104\end{array}$} & \multicolumn{2}{|c|}{$\begin{array}{c}\text { Specific surface } \\
\mathrm{m}^{2} \cdot \mathrm{kg}^{-1} \\
338 \\
\text { (Blaine) }\end{array}$} \\
\hline $\begin{array}{l}\text { Mineral } \\
\text { accordin }\end{array}$ & $\begin{array}{l}\text { composition } \\
\text { gue } \%\end{array}$ & & $\begin{array}{l}{ }_{3} S \\
\cdot 66\end{array}$ & $\begin{array}{c}\mathrm{C}_{2} \mathrm{~S} \\
17 \cdot 13\end{array}$ & $\begin{array}{l}C_{3}^{*} \\
10\end{array}$ & & & $\begin{array}{l}\mathrm{CaSO}_{4} \\
3.65\end{array}$ \\
\hline
\end{tabular}

Table 3. Setting of the cement pastes with the added $\mathrm{PbO}$ admixture.

\begin{tabular}{|c|c|c|c|c|c|c|c|c|}
\hline \multirow[b]{2}{*}{$\begin{array}{l}\text { Admixture } \\
\text { of } \mathrm{PbO}(\%)\end{array}$} & \multicolumn{4}{|c|}{$w / c 0.30$} & \multicolumn{4}{|c|}{ w/c 0.45} \\
\hline & Begin & End & Time & $\begin{array}{l}\text { Compresive } \\
\text { strength } \\
\text { (MPa) }\end{array}$ & Begin & End & Time & $\begin{array}{c}\text { Compresive } \\
\text { strength } \\
\text { (MPa) }\end{array}$ \\
\hline 0 & $3 \mathrm{~h} 40 \mathrm{~min}$ & $5 \mathrm{~h} 40 \mathrm{~min}$ & $2 \mathrm{~h}$ & 29.9 & $6 \mathrm{~h} 16 \mathrm{~min}$ & $>21 \mathrm{~h}$ & $>15 \mathrm{~h}$ & $13 \cdot 7$ \\
\hline 1 & $7 \mathrm{~h}$ & $25 \mathrm{~h} 15 \mathrm{~min}$ & $18 \mathrm{~h} 15 \mathrm{~min}$ & $4 \cdot 1$ & - & - & $27 \mathrm{~h}$ & 0.6 \\
\hline 4 & $7 \mathrm{~h}$ & $27 \mathrm{~h} 15 \mathrm{~min}$ & $20 \mathrm{~h}$ & 0.4 & - & - & $81 \mathrm{~h}$ & 0.2 \\
\hline
\end{tabular}

Table 4. Characteristics of the mortars after their moist curing.

\begin{tabular}{|c|c|c|c|c|c|c|c|c|}
\hline$w / c$ & \multicolumn{2}{|c|}{$\begin{array}{l}\text { Added } \\
\text { metal oxide } \\
(\%)\end{array}$} & \multirow{2}{*}{$\begin{array}{c}\begin{array}{c}\text { Time of } \\
\text { moist curing } \\
\text { (days) }\end{array} \\
10\end{array}$} & \multirow{2}{*}{$\begin{array}{c}\begin{array}{c}\text { Bulk } \\
\text { weight } \\
\left(\mathrm{kg}^{-\mathrm{m}^{-3}}\right)\end{array} \\
2114\end{array}$} & \multirow{2}{*}{$\begin{array}{c}\begin{array}{c}\text { Total } \\
\text { porosity } \\
(\%)\end{array} \\
200\end{array}$} & \multirow{2}{*}{$\begin{array}{c}\begin{array}{c}\text { Pore } \\
\text { median } \\
(\mathrm{nm})\end{array} \\
192\end{array}$} & \multirow{2}{*}{$\begin{array}{c}\begin{array}{c}\mathrm{H}_{2} \mathrm{O} \text { bound } \\
\text { contents } \\
(\%)\end{array} \\
2 \cdot 13\end{array}$} & \multirow{2}{*}{$\begin{array}{c}\begin{array}{c}\mathrm{Ca}(\mathrm{OH})_{2} \\
\text { contents } \\
(\%)\end{array} \\
0.63\end{array}$} \\
\hline \multirow{5}{*}{0.5} & $\mathrm{PbO}$ & 1 & & & & & & \\
\hline & $\mathrm{ZrO}_{2}$ & 1 & 3 & 2139 & $19 \cdot 7$ & 531 & 1.34 & 2.27 \\
\hline & & 4 & 3 & 2156 & 18.8 & 274 & 1.50 & 2.23 \\
\hline & $\mathrm{Cr}_{2} \mathrm{O}_{3}$ & 1 & 3 & 2100 & $21 \cdot 4$ & 291 & 1.62 & 1.41 \\
\hline & & 4 & 3 & 2120 & $20 \cdot 1$ & 431 & 1.38 & 1.28 \\
\hline \multirow{7}{*}{0.7} & plain me & ortar & 3 & 2133 & $19 \cdot 6$ & 343 & $1 \cdot 35$ & 1.08 \\
\hline & $\mathrm{PbO}$ & 1 & 14 & 2035 & $22 \cdot 1$ & 312 & 1.84 & 2.99 \\
\hline & $\mathrm{ZrO}_{2}$ & 1 & 3 & 2035 & $23 \cdot 9$ & 834 & 1.38 & $2 \cdot 44$ \\
\hline & & 4 & 3 & 1999 & 25.0 & 687 & 1.42 & 1.92 \\
\hline & $\mathrm{Cr}_{2} \mathrm{O}_{3}$ & 1 & 3 & 2012 & $24 \cdot 2$ & 789 & 1.44 & 1.60 \\
\hline & & 4 & 3 & 2021 & $23 \cdot 9$ & 775 & $1 \cdot 15$ & 1.80 \\
\hline & plain $\mathrm{m}$ & ortar & 3 & 1990 & $25 \cdot 5$ & 967 & $1 \cdot 30$ & 2.02 \\
\hline
\end{tabular}

An exception represents the $4 \% \mathrm{PbO}$ mortar with $\mathrm{w} / \mathrm{c} 0.7$ differing by relatively lowest short- and long-term values of compressive strength (figures 1 and 2). It shows the disturbing effect of the hardening in the given $\mathrm{PbO}$ mortar. It is interesting that this adverse effect was evoked by the simple increasing by $40 \%$ of $\mathrm{w} / \mathrm{c}$ value used. 
Table 5. Characteristic of the mortar after their air curing.

\begin{tabular}{|c|c|c|c|c|c|c|c|}
\hline$w / c$ & $\begin{array}{l}\text { Added metal } \\
\text { oxide }(\%)\end{array}$ & $\begin{array}{c}\text { Time of } \\
\text { curing (days) }\end{array}$ & $\begin{array}{c}\text { Bulk } \\
\text { weight } \\
\left(\mathrm{kg} \cdot \mathrm{m}^{-3}\right)\end{array}$ & $\begin{array}{l}\text { Total } \\
\text { porosity } \\
(\%)\end{array}$ & $\begin{array}{l}\text { Pore } \\
\text { median } \\
(\mathrm{nm})\end{array}$ & $\begin{array}{c}\mathrm{H}_{2} \mathrm{O} \text { bound } \\
\text { contents } \\
(\%)\end{array}$ & $\begin{array}{c}\mathrm{Ca}(\mathrm{OH})_{2} \\
\text { contents } \\
(\%)\end{array}$ \\
\hline \multirow{6}{*}{0.5} & $\mathrm{PbO}$ & 784 & 2206 & $17 \cdot 1$ & 152 & 1.57 & $4 \cdot 52$ \\
\hline & \multirow[t]{2}{*}{$\mathrm{ZrO}_{2}$} & 770 & 2217 & $17 \cdot 0$ & 388 & $2 \cdot 10$ & 5.85 \\
\hline & & 434 & 2198 & $17 \cdot 3$ & 448 & 1.82 & 3.88 \\
\hline & \multirow[t]{2}{*}{$\mathrm{Cr}_{2} \mathrm{O}_{3}$} & 434 & 2192 & $16 \cdot 8$ & 414 & 1.65 & $4 \cdot 40$ \\
\hline & & 532 & 2269 & $14-2$ & 484 & 1.45 & $4 \cdot 74$ \\
\hline & plain mortar & 840 & 2231 & $16 \cdot 6$ & 476 & 1.57 & 5.85 \\
\hline \multirow{6}{*}{0.7} & $\mathrm{PbO}$ & 448 & 2177 & $17 \cdot 7$ & 479 & $2 \cdot 68$ & 6.89 \\
\hline & $\mathrm{ZrO}_{2}$ & 434 & 2158 & $18 \cdot 2$ & 982 & 2.09 & 6.05 \\
\hline & 4 & 434 & 2088 & $20 \cdot 4$ & 611 & $2 \cdot 11$ & $5 \cdot 68$ \\
\hline & \multirow{2}{*}{$\mathrm{Cr}_{2} \mathrm{O}_{3}$} & 532 & 2215 & $16 \cdot 1$ & 776 & $2 \cdot 32$ & $5 \cdot 71$ \\
\hline & & 658 & 2187 & $16 \cdot 8$ & 601 & $2 \cdot 25$ & $5 \cdot 75$ \\
\hline & plain mortar & 490 & 2122 & $20 \cdot 5$ & 1082 & 2.05 & 5.98 \\
\hline
\end{tabular}

Table 6. Characteristics of the PbO mortars.

\begin{tabular}{lcccccccc}
\hline & $\begin{array}{c}\text { Time of } \\
\text { Added } \\
\text { metal } \\
\text { oxide } \\
(\%)\end{array}$ & $\begin{array}{c}\text { hardening } \\
\text { (days) } \\
(\text { MC-Most } \\
\text { curing) }\end{array}$ & $\begin{array}{c}\text { Bulk } \\
\text { weight } \\
\left(\mathrm{kg} \cdot \mathrm{m}^{-3}\right)\end{array}$ & $\begin{array}{c}\text { Total } \\
\text { porosity } \\
(\%)\end{array}$ & $\begin{array}{c}\text { Pore } \\
\text { median } \\
(\mathrm{nm})\end{array}$ & $\begin{array}{c}\mathrm{H}_{2} \mathrm{O} \\
\text { bounds } \\
(\%)\end{array}$ & $\begin{array}{c}\mathrm{Ca}(\mathrm{OH}) \\
\text { contents } \\
(\%)\end{array}$ & $\begin{array}{c}\text { Compressive } \\
\text { strength } \\
(\mathrm{MPa})\end{array}$ \\
\hline 0.5 & PbO 4 & $30 \mathrm{MC}$ & 2142 & 18.5 & 112 & 2.66 & $1 \cdot 15$ & $34 \cdot 7$ \\
0.7 & $30 \mathrm{MC}$ & 1956 & 27.4 & 828 & 1.13 & 0.26 & 2.2 \\
0.5 & 462 & 2281 & 13.9 & 168 & 2.08 & 5.02 & 44.5 \\
0.7 & PbO 4 & 420 & 2037 & 17.1 & 1699 & 2.30 & 3.61 & 6.3 \\
\hline
\end{tabular}

Comparing the values characterizing the pore structure (bulk weight, total porosity, pore median) and cement hydration degree in the mortars (water bound and calcium hydroxide contents), given in tables 4,5 and 6 , the significant differences can be seen in the values of the $4 \% \mathrm{PbO}$ mortar with $\mathrm{w} / \mathrm{c} 0.7$ and those of other studied $\mathrm{MeO}_{x}$ mortars.

As can be seen this mortar is significantly marked off not only by the decreased compressive strength values, but also by the decreased values of bulk weight, calcium hydroxide contents and water bound contents (after moist curing) and by the increased values of total porosity and pore median. In the case of this parameter the difference was especially expressive.

It is known that compressive strength is dependent on the quality of pore structure of the cement-based materials. This quality is moreover dependent on the kind and quantity of the constituents forming pore structure, as cement hydration products and their reaction products with admixtures. Therefore, the cause of the mentioned paralysis of the $\mathrm{PbO}$ acceleration effect should be searched in the given pore structure and its constituents. From this viewpoint the reaction products of cement 
hydration and $\mathrm{MeO}_{x}$ admixtures in pore structure in the mortars are interesting. Unfortunately, the used DTA and XRD methods for the study of the reaction products have been shown as fully unsuccessful. Evidently the reaction products in question were amorphous or near-amorphous substances and therefore the used methods were unable to identify them. Moreover, the presence of numerical spacings of $\beta$-quartz on the XRD-patterns represents a potential factor for superimposing of the spacings of other present substances in the mortars disturbing their identification.

But the found changes in the degree of the pore structure and cement hydration, under the application of $\mathrm{MeO}_{x}$ admixtures, demonstrate the interaction between hydrating cement components and the added $\mathrm{MeO}_{x}$ admixtures. The results of this interaction were undoubtedly the common products. Therefore the anticipation of their existence in the $\mathrm{MeO}_{x}$ mortars is fully entitled. According to this, $\mathrm{PbO}, \mathrm{ZrO}_{2}$ and $\mathrm{Cr}_{2} \mathrm{O}_{3}$ added to cement seem to be active partners of cement hydration process.

The formation of heavy metal hydroxides of various solubility, or complex compounds and double salts under the presence of heavy metal oxides in hydrating cement is supposed (Chado et al 1967; Poon et al 1985; Cote 1986). The coating of hydrating particles of cement by these compounds is considered for the cause of the disturbing of cement hardening in some cases.

The formation of large hexagonal crystals of $\mathrm{Ca}(\mathrm{OH})_{2}$ due to the presence of some heavy metal oxides, resulting in more porous structure of cement matrix seems to be an undesirable factor occurring due to presence of heavy metal oxides (Tashiro et al 1985).

Some heavy metal ions, including $\mathrm{Pb}^{2+}$ ion, are able to replace part of $\mathrm{Ca}^{2+}$ ions in calcium silicate hydrates leading to their amorphization (Komarneni et al 1988). It is well known that these hydrates play dominant role in cement-based materials. Therefore, it can be accepted that the effects of the mentioned replacement has an important infiuence on the properties of cement-based materials, containing heavy metal oxides.

It is evident that interaction of heavy metal oxides and hydrating cement represents a very complex topic.

Undoubtedly for the behaviour of heavy metal oxide admixtures and their influence on hydration and hardening of cement the chemical properties of heavy metal oxides represent the factor of the first order (Remy 1961). For the studied oxides the following characteristics are probably significant for their effects in question: (i) ability of $\mathrm{ZrO}_{2}$ in strong medium to formate anion $\left[\mathrm{ZrO}_{3}^{2-}\right]$ and on it, based salts containing amorphous hydrated $\mathrm{ZrO}_{2}$. This is able to bind the basic compounds, maybe $\mathrm{Ca}(\mathrm{OH})_{2}$, (ii) $\mathrm{Cr}^{3+}$ ion present in $\mathrm{Cr}_{2} \mathrm{O}_{3}$ has strong tendency to formate complex compounds, $\mathrm{Cr}^{3+}$ ion with the strong bases is able to formate hydroxochromic compounds and (iii) $\mathrm{Pb}^{2+}$ ion formates with the strong bases of lead hydroxo compounds.

It can be supposed that the mentioned characteristics take place in the interaction of $\mathrm{PbO}, \mathrm{ZrO}_{2}$ and $\mathrm{Cr}_{2} \mathrm{O}_{3}$ with hydrating cement and the found effects.

According to the obtained results, the formation of the mentioned species (i,ii,iii) and their existence in the mortars probably were favourable as has been shown by the development of short-term compressive strength and their long-term stability. This positive effect of $\mathrm{PbO}, \mathrm{ZrO}_{2}$ and $\mathrm{Cr}_{2} \mathrm{O}_{3}$ admixture on other engineering properties of cement-based materials can be supposed. Moreover the positive effect seems to be independent of $\mathrm{w} / \mathrm{c}$ ratio value used. It is important under suitable circumstances from a practical viewpoint. 
An exception demonstrating as a paralysis of accelerating effect by $\mathrm{PbO}$ admixture under the increasing of $\mathrm{w} / \mathrm{c}$ ratio value shows the complexity of the interaction. The changed conditions of hydrolysis or the increasing of the quantity of the formated reaction product, overstepping the optimum, seem to be as a potential possibility of the paralysis.

\section{Conclusion}

(I) The obtained results show that immobilized $\mathrm{PbO}, \mathrm{ZrO}_{2}$ and $\mathrm{Cr}_{2} \mathrm{O}_{3}$ in cement matrix positively influence its engineering properties and their long term stability. An interesting and important information is the possibility of the paralysis of the positive effect of the immobilized $\mathrm{PbO}$ when the w/c used is increased.

(II) The found strengthening and strength-degradation effects under heavy metal oxides immobilization in cement matrix are worthy of a more detailed study.

\section{Acknowledgement}

The author thanks Slovak grant agency VEGA for partial support to this work.

\section{References}

Arliquie G, Ollivier J P and Grandet G 1983 Cem. \& Concr. Res. 13379

Barth E E et al 1990 Solidification of hazardous wastes (Park Ridge, New York: Noyes Data)

Coté D $1986 \mathrm{Ph}$. D. Thesis, University of Hamilton, Ontario, Canada

Chado A, Shikami G and Egaki E 1967 Semento gijitsu Nonpo 2164

Fierens P and Verhaegen J P 1972 J. Am. Ceram. Soc. 55309

Gilliam T M, Dole L R and McDaniel E W 1986 Waste immobilization in cement-based grouts(Detroit: ASTM Sp. Tech. Pub.) p. 295

Kakali G, Kasselouri V and Parissakis G 1989 Cem. \& Concr. Res. 19968

Komarneni S, Breval E, Roy D M and Roy R 1988 Cem. \& Concr. Res. 18204

Poon C S, Clark A J, Peters C J and Perry R 1985 Waste Management and Research 3127

Remy H 1961 Lehrbuch der anorganische chemie, band II (Leipzig: Academische Verlag)

Roy R 1982 Radioactive waste disposal, in The waste package (New York: Pergamon Press) Vol. 1, p. 232

Takashi H, Kanaya M, Hirakida I and Yoshida R 1977 Cem. \& Concr. Res. 7283

Tashiro C 1984 Proc. 8th int. congress of the chemistry of cement, Rio de Janeiro, 5 p. 226

Tashiro C, Uecka K and Tashibana S 1985 Proc. SILICONF, Budapest (Hungary: Hungary Academy of Sciences) p. 281

Živica V 1994 Building Res. J. 42.367

Živica V and Vargová M 1995 Building Res. J. 43115

Živica V and Janotka I 1996 Proc. durability of building materials and components: Prediction, degradation and materials, Proc. 7th DBMC, Stockholm, Sweden, (London: E \& FNSPON) Vol. 1, p. 259 